\title{
THE IMPLEMENTATION OF BLOG BASED LEARNING IN INTERPRETING CLASS AT THE SIXTH SEMESTER STUDENTS OF ENGLISH EDUCATION DEPARTMENT
}

\author{
Nur Isnaini Wulan Agustin \\ Universitas Pendidikan Indonesia
}

\begin{abstract}
Blogs Based Learning is one of media in teaching which brings significant role unexceptionally in interpreting class. This study aims to describe the implementation of Blog Based Learning in interpreting class, which would become more sustainable by ... of the use of currently popular technology. This research is conducted to gain insights into the implementation of Blog Based Learning, problems faced by the teacher, and solutions to solve those problems. The researcher got the data from scripton, event, information, and document. The techniques of collecting data are the observation, interview and documentation in teacher's blogs to clarify the implementation of Blog Based Learning. The finding showed that the implementation of Blog is well executed although the uses of blogs are not fully carried out in interpreting class fully. The challenges faced by the teacher in implementing the blogs are mostly related to teacher's lack of management to maximize Blog Based Learning and the difficulty in improving students' awareness. There are several solutions proposed by the teacher in the implementation of Blog Based Learning are building a good management and communicating the importance of active participations in interpreting class through blogs. Some students have low awareness in accessing blogs for additional source for their learning. Both teacher and students required to collaborate each other in making good media for teaching and learning process.
\end{abstract}

\section{KEYWORD:}

Implementation, Blog Based Learning, Interpreting Class

\section{INTRODUCTION}

Blogs are simply online diaries written by bloggers. A space for individuals to write whatever they choose, with an option for readers to comment on what they have read. Blogs can be fascinating, or utterly tedious. They can be elegant or clunky, informed, or bigoted (Eastment, 2005: 358-361). This media uses in the class as a discussion class of what material they have worked in the blogs. 
Likewise, Campbell (2004: i-ii) discusses the possibilities of integrating blogs into educational context, especially in language teaching field and mention three types of blogs that are likely to be beneficial in teaching language learners. Blogs are well known to teach writing in the classroom. The activities in blogging are significant to improve writing skill. Blogs are a timely arrive which can fulfill many of needs identified for the effective teaching of writing. This use of currently popular technology is also meant to ensure sustainability of the instruction.

Interpreting is an ancient human practice which clearly predates the invention of writing and (written) translation. In many Indo-Europan languages, the concept of interpreting is expressed by words whose etymology is largely autonomous from that of (written) translation (Pochhacker, 2004: 9). Writing is the first tool before doing interpreting. Moreover, there is the type of interpreting which needs note taking before doing interpreting. Note taking is a special characteristic of consecutive interpreting (Pujiyanti, 2013: 7). It is relevant with the situation in interpreting, the interpreter sits with the participants in the conference room and take notes of what being said. At the end of each statement, he gives an oral translation, with or without the help of his note.

It is very needed to underline that blogs create in interpreting class. Bridging the difference between real interpreting and interpreting class have to understand. Real interpreting is the activity in the field. Real interpreting did in live situation. It will be not possible using blogs in the live activity. While, interpreting class divided into two categories of material: theory and practical.

In interpreting class at the sixth semester students of English Education Department, teacher creates learner blogs to give reinforcement to students in writing to prepare interpreting class. Teacher posted different topic for discussing material in the class. Setiawan (2011: 4) describes some advantages coming from blogs itself both from teachers and students.

Considering the roles of blogs in language learning, it is expected, through blogs, students motivated to learn, express their idea in a written form then deliver it in a spoken well in practicing interpreting in students' classroom.

\section{LITERATURE REVIEW}

There are many theories of blogs. One of them is stated by Campbell (2004: i). He stated that blogs can be tought of as an online journal that an individual can continuously update with his or her own words, ideas, and thoughts trough software that enables one to easily do so. Unlike a standart website, blogs entries are made by typing directly into the browser and with the click of a button are instantly published on the internet. Similar to an open journal, the accumulation of writings and other content creates both a record of learning and a resource for others. furthermore, blogs are interactive, in the sense that readers can respond to any given entry with a comment and even threaded discussion can take place. 
According to Parisi and Corby (2012: 4), blogging is so much more than simply a site of chronologically posted writing. It is a place for students to practice their writing and communication skill. Students have to think what will they write then share in blog.

Blogging (Walatka, 2002: 373) is pedagogical tools offers great support to the teacher who wants help students actively engage the course material and move beyond lecturing (although it helps with formulating interesting lectures as well). Student blogging can be an effective tool for helping students engage material and for creating a foundation from which student discussion and dialogue can flow.

Interpreting is defined as an effort for rendering the source language into the target language orally. As stated by Shuttleworth and Cowie in Pujiyanti (2013: 1), interpreting is a term used to refer to the oral translation of a spoken message or text.

Nababan (2003: 114) also stated opinion that interpreting: "Transfering language refers to the oral communication situation which source speakers process the information that they get into target language and the third process." There are three general categories of current interpreting research. Firstly, interpreting practice which concerns articles on interpreting. For example, interpreting process or product. Then, interpreting training and assesment which involves all aspects of the learning and teaching of interpreting. Lastly, review of interpreting research which focuses on studies about interpreting research, including articles discussing relevant research methods in the field or review studies. It can be concluded that interpreting class is a set of classes or a plan of study on a interpreting subject.

\section{RESEARCH METHOD}

In this research, the researcher used qualitative research. This type of the research is descriptive qualitative research which focused to the teacher's blog to help students in teaching learning process. In qualitative research, as suggested by Sugiyono (2015: 19), the researcher investigated the activities, situations or materials seriously. Researcher did observation and analysis about the phenomenon. In this research, the researcher used four kinds of techniques of collecting the data; those are (1) observation, (2) interview, and (3) documentation. The data were analyzed through an interactive model analysis by Miles and Huberman (1994); reducing data, displaying data, and drawing/ verifying conclusion. The data displayed in description form. In the last, they were drowned into conclusion.

\section{Findings And Discussion}

\section{a. Description on the Implementa- tion of Blog Based Learning in Interpreting Class}

Blogs are the discussion place in interpreting class which used by teacher in interpreting class. Teacher designed her blog as learner blogs. Blogs positioned in interpreting class as a suplementary media. Blogs used in interpreting class before the class. Blogs accessed by the 
teacher and students a night before the classroom. Teacher posted the topic discussion then students gave comments actively. The process of Blog Based Learning in interpreting class did outside the classroom. When interpreting class in the classroom, teacher and students only reviewed what they discussed a night before. Teacher continued to teach material or do practice after discussing students' comments in teacher's blog, that's why this use of technology will likely make the instruction sustainable.

\section{b. Description on the Implementa- tion of Blog Based Learning in Interpreting Class}

Teacher positioned herself in using blogs is as a facilitator. It could be seen when teacher gave material in her blogs and prepare the good facility when teaches in interpreting class. Teacher in blogs is also blog's owner. Teacher is motivator who stimulate students in learning, and investigator.

\section{c. The Students' Role in Teaching Interpreting Using Blogs}

Students' role in blogs as a language learning are: receiving questions from lecturer, respond teacher's question, download material from their teacher, giving comment actively. While when in the clasroom, students have to watch video which prepared by teacher, make conversation about interpreting material, practice in front of the class, receive feedback after having practice, do assignment individually and sometimes in a group. d. Problem Faced by the Teacher in Implementation Blog Based Learning in Interpreting Class

There are two problems which faced by the teacher, those are:

a. Lack of management to maximize blogs and how to implement media for students well

The teacher stated that she did not post discussion topic in blogs in every meeting. She only implemented in the beginning of meeting and in the last meeting. She explained that she was able to use in every meeting from the beginning untill the end. Lack management here was not about the difficulty in implementation blogs in interpreting class but lack managemnt in how to use blogs maximally in classroom.

b. The Difficulty in Improving the Student's Awareness.

Teacher has given encouraging word to students to be active in blogs because it will give them additional score. Some students dis not care about that. Students' discussion did not maximize because not all students gave their comments. Teacher felt the difficulty to improve students' awareness to be active.

\section{e. Solutions Proposed by the Teach- er to Solve Problems in Imple- mentation Blog Based Learning in Interpreting Class}

The teacher faced some problems in implementation Blog Based Learning. To solve problems, teacher proposed some solutions. Those are: 
a. Building a Good Management on Implementation Blogs

Teacher realized in implementing blogs, there are some problems. Teacher did not use blogs every week before class. Thereby, teacher should build a good management as her evaluation to the next implementation of blogs in learning.

b. Comunicating the Importance of Activeness in Interpreting Class through Blogs

The teacher have to communicate the importance of activeness in interpreting class as can as possible. The teacher should stimulate by giving reward to active students. Thus, students will aware that blogs is important. They have to give participation in teacher's blogs which gave them benefits.

\section{Conclusion}

Blogs are the place for creating online discussion between students and teacher. Blogs are on of the media which can help students in learning. Teacher are able to implement blogs in interpreting class. Implementation of Blog Based Learning in interpreting class in term of teacher's role and students' role.

Blogs are used in interpreting class as a suplementary media for helping students in discussion about interpreting subject material. The teacher positioned herself as facilitator in her blogs. She posted learning material, students' assignment and topic discussion in blogs. Those knowledge is for students to enhance their knowledge in interpreting class in order to gain the academic goals. The teacher taught in interpreting class about theory and practice. Blogs are significant for students in mastering the material that related to the theory. Students' role in blogs is as readers that have to give comments in teacher's blogs when the discussion in blogs begin. They are able to read the whole contents of teacher's blog although the postings are about other scientific works. Students did not change the blogs because blogs only are able to edit by teacher. Teacher designed blogs for creating students activeness in the classroom and blogs thus the learning process of interpreting class will be effective.

Problem faced by the teacher in implementation of Blog Based Learning in interpreting class are teacher's lack of management to maximize Blog Based Learning and how to implement media for students well and the difficulty in improving students' awareness.

The teacher proposed some solutions to solve problems in implementation Blog Based Learning in interpreting class: building a good management on implementation blogs and communicating the importance of activeness in interpreting class through blogs.

\section{REFERENCE}

A.P. Campbell. 2004. Using Live Journal for Authentic Communication in EFL Classes. The Internet TESL Journal Vol 10 no 9.

Eastment, Diana. 2005. "Blogging". ELT Journal, Vol 59 no 44.

Miles, M. B., \& Huberman, A, M. 1994. Qualitative Data Analysis (2nd Ed). 
California: Sage Publication.

Nababan, M. R. 2003. Teori Menerjemah Bahasa Inggris. Yogjakarta: Pustaka Pelajar.

Parisi, L and Brian Crosby. 2012. Making Connection with Blogging. International Society for Technology in Education Publisher.

Pochhacker, Franz. 2004. Quality Assesment in Conference and Community Interpreting dalam META : Translator's Journal. Vol 46 n 2, 2001, p. 410- 425 http://erudit.org/ iderudit/003847ar.

Pujiyanti, Umi. 2013. Kajian Penerjemahan Lisan. LKP: Indonesia Belajar.
Setiawan, Aziz Oka. 2011. Improving Student Writing Skill by Using Web Blog (A Classroom Action Research at the Second Grade of SMA N Colomadu on the Academic Year 2010/ 2011). Skripsi pada FKIP Pendidikan Bahasa Inggris UNS Surakarta: Tidak diterbitkan

Sugiyono. 2006. Metode Penelitian Pendidikan Pendekatan Kuantitatif, Kualitatif and R\&D). Bandung: Alfabeta.

T. Walatka. 2012. Hub-and Spoke Student Blogging and Advantages for Classroom Discussion. Teaching Theology and Religion Journal, Vol 15, Issue 4, Oktober 2012. Blackwell Publishing Ltd. 